\title{
The Effect of Aureomycin on the Gut of the Pig
}

\author{
By R. BRAUDE, MARIE E. COATES, MARY K. DAVIES, \\ G. F. HARRISON AND K. G. MITCHELL \\ National Institute for Research in Dairying, University of Reading
}

(Received 7 May 1955)

\begin{abstract}
Antibiotics given in the diet have been shown to reduce the weight of the chick's intestine; Gordon (1952) demonstrated this effect with penicillin, and Pepper, Slinger \& Motzok (1953) with aureomycin (chlortetracycline). In our own studies with chicks (Coates, 1953; Coates, Davies \& Kon, 1955) we found a marked reduction in the weight of the small intestine when procaine penicillin was given in the diet, but were unable to obtain evidence of any chemical or histological changes to account for the loss. The experiments reported here have been undertaken to study whether or not antibiotics have a similar effect on the pig's gut. It was hoped that if the gut weight were reduced, any changes in the structure of the gut would be more easily observed in the pig than had been possible in so small a subject as the chick. It seemed of interest also to determine the effect of the antibiotic on the weights of other organs besides the gut.
\end{abstract}

\section{EXPERIMENTAL}

Management of the animals. Large White weaners, 9-12 weeks old at the beginning of the experiments, were used. The pigs were individually fed twice daily, according to live weight, on a basal meal mixture consisting of fine miller's offal 50 , barley meal 30, flaked maize 10 and white fish meal 1o, all parts by weight. Each pig received once weekly $\mathrm{I}$ oz. cod-liver oil added directly to the trough, and water at the rate of $3 \mathrm{lb}$. to every lb. of meal was added immediately before feeding. Aurofac $2 \mathrm{~A}$ (Lederle Laboratories Inc.), containing $3.6 \mathrm{~g}$ aureomycin/lb., was added at the rate of $5 \mathrm{lb}$./ $2000 \mathrm{lb}$. diet to the basal meal of one of each pair of animals. There was no direct contact between the control pigs and those receiving the antibiotic-supplemented diet .

Measurements of the organs. The small intestine, from the pylorus to the ileo-caecal junction, was removed from the animal at slaughter. The contents were squeezed out and the gut was washed in cold running water. Its length was measured to the nearest $\frac{1}{4}$ yd. against a yardstick. It was then weighed, after detaching any adhering mesenteric fat.

In the first experiment with pigs killed at bacon weight the liver, kidneys and spleen were also removed at slaughter, cleaned of any extraneous tissue and weighed.

Preparation of the gut for analysis. The weighed intestine was roughly chopped into pieces and homogenized in a Waring Blendor. The Blendor was too small to deal at once with the whole intestine which was therefore homogenized in several portions; 
these were then pooled in a mechanical mixer. Duplicate samples for all analyses were taken immediately.

Determination of dry matter. A ro g sample was taken in a shallow aluminium dish and dried to constant weight in an oven at $98^{\circ}$, which was usually achieved in about $4^{-5} \mathrm{~h}$.

Determination of fat. A ro g sample was weighed into a boiling tube and digested with about $\mathrm{io} \mathrm{ml}$. conc. $\mathrm{HCl}$ on a water-bath. When cool, the mixture was extracted with $50 \mathrm{ml}$. of a mixture of equal parts of light petroleum (b.p. $40-60^{\circ}$ ) and diethyl ether and then with two further lots, each of $30 \mathrm{ml}$., of the solvent mixture. The combined extracts were transferred to a weighed flask, evaporated to dryness and weighed, after removal of the last traces of solvent under reduced pressure.

Determination of total nitrogen. Total nitrogen was determined on $5 \mathrm{~g}$ samples by the macro-Kjeldahl method.

Statistical analysis of the data. Since the weight of the organs is, to some extent, dependent upon body-weight, the results were treated by analysis of covariance (Snedecor, 1940), and the organ measurements were adjusted to a constant body-weight. When litter-mates were used, the variance between litters was eliminated. The significance of difference between groups was calculated from the covariance analysis.

Experimental procedure. A preliminary trial was carried out with five pairs of littermates, which were killed at pork weight after 12 weeks on experiment. One of each pair was given the basal diet with, and one without, aureomycin. The small intestine of every animal was weighed immediately after slaughter.

Two further experiments were done on animals slaughtered at bacon weight I4-I 8 weeks after the beginning of the experiment. The first of these involved thirteen pairs of litter-mates, again one of each pair receiving the basal meal with, and one without, aureomycin. Gut length and weight were determined immediately after slaughter. From the first nine pairs of pigs the liver, kidneys and spleen were also weighed and determinations of dry matter, fat and total $\mathrm{N}$ were made on the gut.

In the last experiment there were not enough pigs available for litter-mate comparisons, and the treatments were allocated at random to eight pairs of pigs of similar initial weights. Measurements of weight and length were made on the intestine, but no other organs were examined. After weighing, some of the intestines were slit longitudinally and preserved in formol-saline for histological examination.

\section{RESULTS}

Preliminary trial. In the preliminary trial with five pairs of porkers, the pigs receiving aureomycin reached a mean live weight of ${ }_{153} \mathrm{lb}$., compared with $142 \mathrm{lb}$. attained by the controls, whereas their mean gut weight was $1428 \mathrm{~g}$, against $1486 \mathrm{~g}$ for the control animals.

Experiment $\mathrm{I}$. In the first experiment with bacon pigs there was an increase in bodyweight and a decrease in gut weight, both of which were significant, in the aureomycin- 
treated animals. The apparent reduction in gut length was not significant. The mean results are shown below:

\begin{tabular}{|c|c|c|c|c|c|c|}
\hline & $\begin{array}{c}\text { No. of } \\
\text { pigs }\end{array}$ & $\begin{array}{l}\text { Body- } \\
\text { weight } \\
\text { (lb.) }\end{array}$ & $\begin{array}{l}\text { Gut } \\
\text { weight } \\
\text { (g) }\end{array}$ & $\begin{array}{l}\text { Adjusted } \\
\text { gut } \\
\text { weight } \\
\text { (g) }\end{array}$ & $\begin{array}{c}\text { Gut } \\
\text { length } \\
\text { (yd.) }\end{array}$ & $\begin{array}{l}\text { Adjusted } \\
\text { gut } \\
\text { length } \\
\text { (yd.) }\end{array}$ \\
\hline Basal diet & 13 & I 79 & I52I & 1560 & $2 I \cdot I$ & $2 x \cdot 3$ \\
\hline Diet with aureomycin & 13 & 197 & $145^{6}$ & 1416 & 20.8 & 20.7 \\
\hline $\begin{array}{l}F^{*} \\
P \dagger\end{array}$ & & $\begin{array}{c}6.0 \\
0.05>P>0.01\end{array}$ & & $\begin{array}{c}5.2 \\
0.05>P>0.01\end{array}$ & & $\begin{array}{r}1.9 \\
>0.5\end{array}$ \\
\hline
\end{tabular}

For the first nine pairs of baconers the figures for organ weights and chemical analysis of the gut are given in Table $\mathrm{I}$. There was a significant increase in body-weight $(P<0.05)$ in the animals given aureomycin. Gut weight and gut length, adjusted to constant body-weight, were both reduced, but only the reduction in length was significant $(P=0.05)$. No change in fat, moisture or total nitrogen content of the gut

Table r. Effect of aureomycin on organ weights and chemical composition of the gut of nine pairs of pigs kept on experiment from weaning to bacon weight

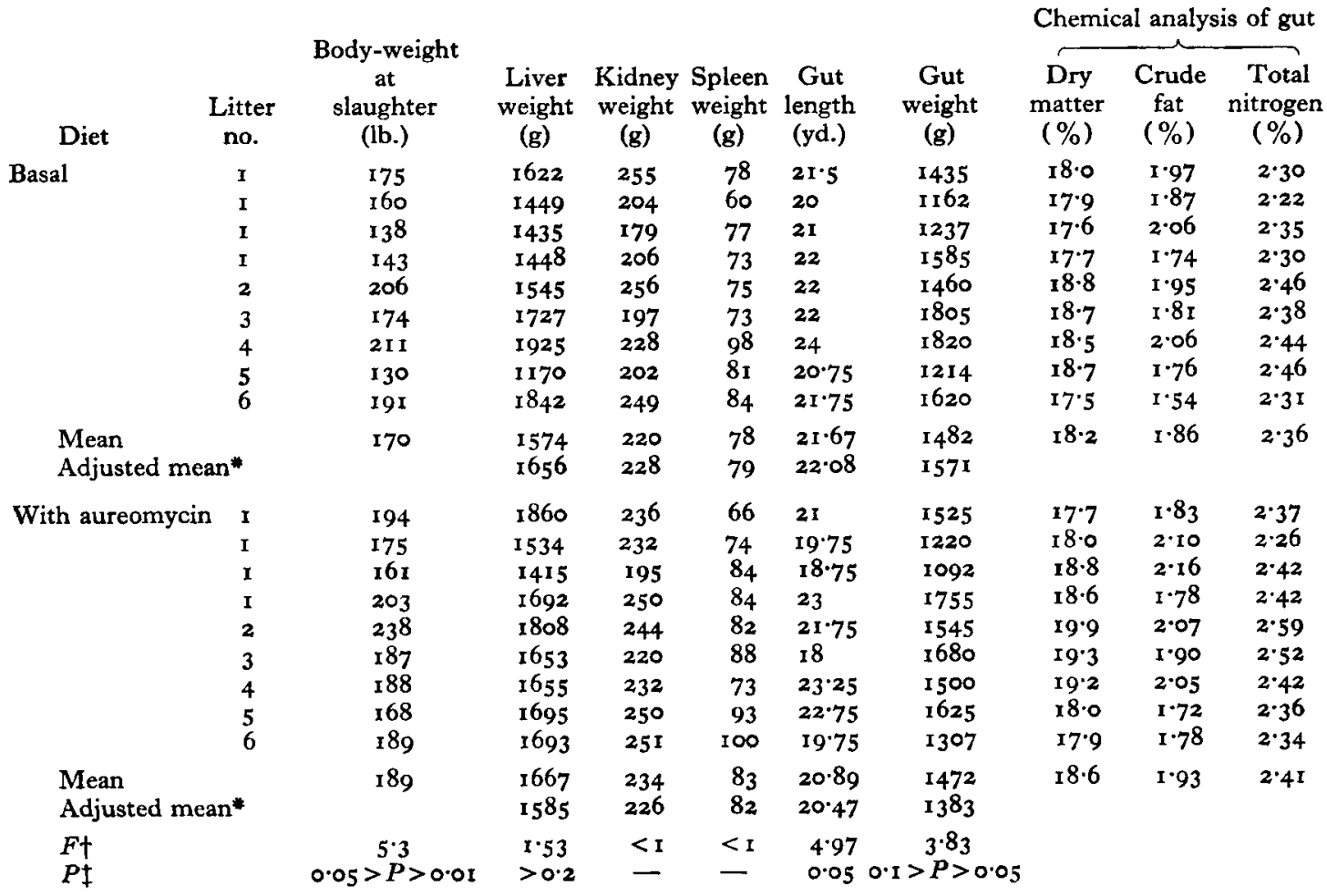

* Calculated from covariance analysis.

+ Variance ratio $\left(e^{2 z}\right)$.

$\ddagger$ Probability of the difference arising by chance in a homogeneous population. 
was observed, nor were the weights of the liver, kidneys or spleen markedly altered by the antibiotic treatment.

Experiment 2. The second experiment on groups of eight bacon pigs, not littermates, gave the following results:

\begin{tabular}{|c|c|c|c|c|c|c|}
\hline & $\begin{array}{l}\text { No. of } \\
\text { pigs }\end{array}$ & $\begin{array}{c}\text { Body- } \\
\text { weight } \\
\text { (lb.) }\end{array}$ & $\begin{array}{c}\text { Gut } \\
\text { weight } \\
\text { (g) }\end{array}$ & $\begin{array}{l}\text { Adjusted } \\
\text { gut } \\
\text { weight } \\
\text { (g) }\end{array}$ & $\begin{array}{c}\text { Gut } \\
\text { length } \\
\text { (yd.) }\end{array}$ & $\begin{array}{l}\text { Adjusted } \\
\text { gut } \\
\text { length } \\
\text { (yd.) }\end{array}$ \\
\hline $\begin{array}{l}\text { Basal diet } \\
\text { Diet with aureomycin }\end{array}$ & $\begin{array}{l}7^{*} \\
8\end{array}$ & $\begin{array}{l}199 \\
212\end{array}$ & $\begin{array}{l}1460 \\
1486\end{array}$ & $\begin{array}{l}\text { I } 507 \\
\text { I } 444\end{array}$ & $\begin{array}{l}23 \cdot 75 \\
24 \cdot 3^{8}\end{array}$ & $\begin{array}{l}24 \cdot 1 \\
24 \cdot 0\end{array}$ \\
\hline$F †$ & & $\mathrm{I} \cdot 8$ & & $<I$ & & $<\mathrm{I}$ \\
\hline$P \downarrow$ & & 0.2 & & - & & - \\
\hline
\end{tabular}

On this occasion, although in the treated pigs body-weight was greater and the adjusted gut weight less, neither effect was significant. The adjusted gut length was almost the same in both groups. Some of the intestines were examined macroscopically in an attempt to assess the amount of lymphatic tissue present. The number and size of the Peyer's patches were estimated, but no difference could be observed between the guts from treated and untreated animals. As the effecton the gut had been so small, no more detailed histological study was undertaken.

General. The results of all experiments considered together show a tendency for the gut weight to be reduced in the aureomycin-treated pigs, but the effect on gut length was less marked. Thus it appeared that in the pig, as in the chick, the gut was thinner as a result of antibiotic treatment. In the two experiments in which the gut length was determined the weight per unit length of intestine for all animals was calculated, and analysis of variance gave the following results:

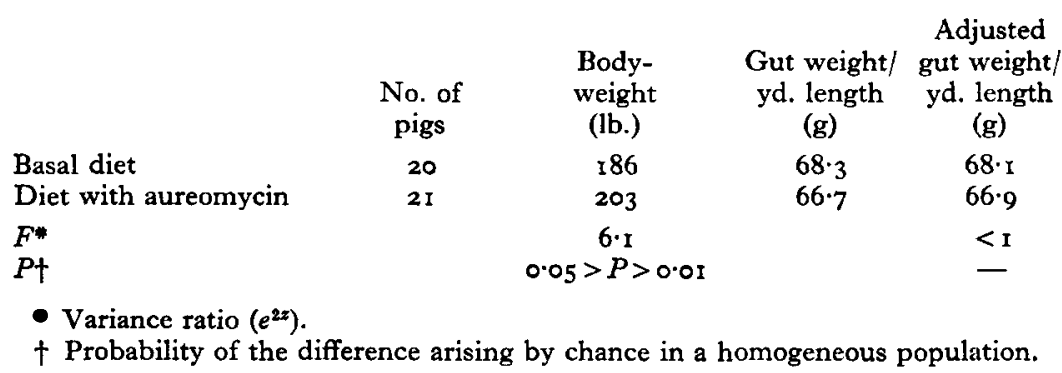

Although the weight of the gut per unit length seemed less in the pigs given aureomycin, the difference was too small to be significant. 
DISCUSSION

In these experiments with pigs there was a tendency for aureomycin to reduce the weight of the small intestine, but the effect was less well marked than we had found in previous experiments with chicks given penicillin (Coates et al. 1955). There was little consistent effect on length, so that the reduction in weight was due to a thinning rather than a shortening of the gut. Although the difference in weight was not great, it was probably sufficient for any alteration in the fat, moisture and total nitrogen contents of the gut to be detected if it had occurred; however, chemical analysis of the gut revealed no such change.

These results support those reported by Taylor \& Harrington (1955) who found that aureomycin feeding significantly reduced the weight of the small intestine of pigs killed at about $200 \mathrm{lb}$. live weight. Contrary to our findings, however, the spleen weight was significantly lower in their antibiotic-supplemented animals.

The results reported here do not add much to the evidence on the mechanism by which antibiotics reduce gut weight. The results with chicks suggested that suppression of an unidentified 'infection' preventing maximal growth rate is accompanied by reduction in the weight of the intestine. It is not known whether an analogous condition exists in pigs, but it is possible that in the pig also the thinning of the gut resulting from feeding aureomycin indicates the elimination of some deleterious micro-organism(s).

A lowering of the number, or alteration in the type, of micro-organisms present in the gut might result in the formation of less lymphoid material and hence in a thinner gut wall. With this possibility in view we examined the intestines from the final experiment. Unfortunately, on that occasion the antibiotic had very little effect on gut weight, so that our failure to detect any gross differences in quantity of lymphatic tissue has little meaning. In any event, since the pig intestine is specially rich in lymphatic tissue, any change might need to be fairly substantial to be detectable.

\section{SUMMARY}

I. In three experiments, involving a total of fifty-two pigs, aureomycin was given in a normal fattening ration at the rate of $20 \mathrm{~g} / \mathrm{ton}$ in the form of Aurofac $2 \mathrm{~A}$ (Lederle Laboratories Inc.) from weaning until slaughter at pork or bacon weight.

2. Immediately after slaughter the weights and lengths of the small intestines were measured. A few of the intestines were examined for histological changes. Determinations of fat, moisture and total nitrogen were made on the gut of nine pairs of pigs, and the liver, kidneys and spleen of these animals were also weighed.

3. In all experiments there was a tendency for gut weight, adjusted to constant body-weight, to be reduced in the aureomycin-supplemented pigs.

4. There was no significant effect on the weights of the liver, kidneys or spleen, nor was there any consistent effect on gut length, which indicated that the reduction in weight was due to a thinning rather than to a shortening of the gut.

5. No chemical or histological changes in the intestines were detected. 
We should like to record our gratitude to our colleague, Mr G. K. Benson, for histological examination of the gut, and to the Directors of M. Venner and Sons Ltd, Bacon Curers, Reading, for slaughterhouse facilities and helpful co-operation.

\title{
REFERENCES
}

Coates, M. E. (1953). Chem. EF Ind. p. 1333.

Coates, M. E., Davies, M. K. \& Kon, S. K. (1955). Brit. Y. Nutr. 9, 110.

Gordon, H. A. (1952). In $A$ Colloquium 'Studies on the Growth Effect of Antibiotics in Germ-free Animals'. Notre Dame, Indiana: Lobund Institute, University of Notre Dame. (Mimeo.)

Pepper, W. F., Slinger, S. J. \& Motzok, I. (1953). Poult. Sci. 32, 656.

Snedecor, G. W. (1940). Statistical Methods, 3rd ed. Ames, Iowa: Iowa State College Press.

Taylor, J. H. \& Harrington, G. (1955). Nature, Lond., 175, 643.

\section{Influence of Diet on the Acute Toxicity of Hypoglycin-A in Rats}

\author{
By P. C. FENG ANd E. A. KEAN \\ Divisions of Pharmacology and Biochemistry, Department of Physiology, \\ University College of the West Indies, Jamaica, B.W.I.
}

(Received I May 1955)

Hypoglycin-A (Hassall, Reyle \& Feng, 1954), is a toxic polypeptide isolated from the fruit of Blighia sapida-known as the ackee in Jamaica. The toxin produces an acute hypoglycaemia and a depletion of liver glycogen in experimental animals. The fruit is a common dietary item locally, and it has been suspected as one of the causes of 'vomiting sickness', which is an acute syndrome with high mortality usually occurring in Jamaican children with a history of malnutrition (Jordan \& Burrows, 1937; Evans \& Arnold, 1938; Hill, 1952; Jelliffe \& Stuart, 1954). Since dietary deficiency has been suggested as a contributing factor in 'vomiting sickness', the present study was undertaken to examine the relationship between the local diet and the acute toxicity of hypoglycin-A in rats.

\section{EXPERIMENTAL}

Plan of experiment. Three groups of rats were fed respectively on the following diets: (a) a high-carbohydrate, low-protein diet, designated as 'Jamaican diet', comprised mainly of items of vegetable origin commonly consumed by the poorer classes of Jamaicans; $(b)$ the same diet, modified by the replacement of some of the carbohydrate with casein, designated as 'modified Jamaican diet'; and $(c)$ the stock diet, which served as a control. The relative toxicity of hypoglycin-A in the different groups was then compared.

Animals. Albino rats of both sexes from the stock colony were weaned on to the experimental diets at 5 weeks of age, at which time they weighed from 50 to $70 \mathrm{~g}$. Diets, and water with I \% sodium chloride, were fed ad lib. In addition to eighty 